\title{
Pelestarian Kawasan Konservasi di Kota Semarang
}

\author{
Eko Punto Hendro \\ email: \\ Fakultas Ilmu Budaya Universitas Diponegoro Semarang
}

\begin{abstract}
Abstrak: Kota Semarang memiliki beberapa kawasan yang strategis untuk dijadikan kawasan konservasi. Kota Lama, daerah Pecinan, PasarJohar, dan Kampung Sekayu merupakan kawasan bersejarah yang harus dikonservasi. Penelitian ini menggunakan metode observasi dan pengembangan model konservasi. Konservasi kawasan diperlukan untuk memberikan perlindungan kawasan-kawasan tersebut dari gencarnya pembangunan kota, termasuk mengendalikan perkembangan kawasan tersebut agar tidak hilang identitas kesejarahaan dan kebudayaannya. Kawasan konservasi ini juga merupakan potensi yang dapat dikembangkan menjadi destinasi dan atraksi wisata.
\end{abstract}

Kata kunci : Semarang, konservasi, identitas, pariwisata

\begin{abstract}
Semarang city has several strategic areas to be used as conservation areas. The Old Town, Chinatown, Pasar Johar, and Kampung Sekayu are historic areas, which must be preserved. This research used observation method and development of conservation model. Conservation area is required to provide protection to the historic district in the city of Semarang from the incessant city development, including controlling the development of the region so that the historical and cultural identity is not lost. This conservation area has the potential to be developed into tourist attraction and destination.
\end{abstract}

Keywords: Semarang, conservation, identity, tourism

\section{Latar Belakang}

Kota Semarang merupakan ibukota Provinsi Jawa Tengah dan termasuk dalam kategori kota besar di Indonesia yang memiliki ketiga aspek utama dari pengembangan kota berkelanjutan, yaitu pengembangan kota dengan mengedepankan keseimbangan antara aspek ekonomi, lingkungan hidup, dan perlindungan cagar budaya yang ada di dalamnya. Saat ini oleh Pemerintah Pusat, Kota Semarang juga dinominasikan ke dalam 10 Kota Pusaka Nasional untuk diusulkan sebagai World Heritage ke UNESCO.

Konservasi kawasan bersejarah merupakan kegiatan pelestarian cagar budaya, dan hasilnya dapat menjadi sumber pendapatan masyarakat dan pemerintah daerah. Konservasi kawasan diperlukan untuk memberikan perlindungan terhadap kawasan bersejarah di Kota Semarang dari gencarnya pembangunan kota, termasuk mengendalikan perkembangan kawasan tersebut agar tidak hilang identitas kesejarahaan dan kebudayaannya. Undang-Undang Nomor 11 Tahun 2010 tentang Cagar Budaya memberikan arahan dan jaminan untuk kegiatan konservasi ini.

Untuk selanjutnya kawasan konservasi dapat diberdayakan melalui media advertising, entertainment dan tourism yang tidak bertentangan dengan prinsip-prinsip konservasi, agar kawasan tersebut dapat menghidupi dirinya sendiri, dan selebihnya dapat pula meningkatkan pendapatan masyarakat maupun pemerintah kota. Art Gallery, Café \& music night, kuliner dan restoran ataupun yang lainnya merupakan kegiatan yang dapat ditawarkan untuk menghidupkan kawasan ini.

Sudah sejak lama beberapa bangunan di kawasan Kota Lama Semarang dilindungi dengan undang-undang tentang cagar budaya dan peraturan daerah namun hingga kini belum ada upaya yang serius dari Pemerintah Kota Semarang untuk melestarikannya sehingga banyak bangunan yang tidak terawat, rusak, bahkan ada yang roboh dengan sendirinya. Banyak kalangan yang mengharapkan kawasan Kota Lama Semarang ini hidup sebagai kawasan konservasi, sekaligus menjadi kawasan wisata sejarah. Banyak orang menginginkan bangunanbangunan kuno di Kota Lama itu terawat dan difungsikan dengan baik. Sebagai contoh, yaitu pemanfaatan bangunan untuk restoran Ikan Bakar Cianjur di Kota Lama Semarang yang menyajikan menu utamanya makanan ikan air tawar. Pengelola restoran benar-benar merawat dan mempercantik bangunan kuno tanpa merubah bentuk aslinya sehingga para pengunjung sangat senang dan menikmatinya, baik makanannya maupun tempatnya. Gereja Blenduk dan Gereja Gedangan juga 
merupakan bangunan yang sangat kuno yang benarbenar dirawat oleh umatnya. Bangunan kuno akan sangat cantik dan unik apabila benar-benar dirawat, dan akan melebihi kecantikan bangunan yang baru. Barangkali saat ini orang akan kagum melihat bangunan baru, tetapi akan sangat terkagum-kagum apabila melihat bangunan kuno yang terawat. Walaupun demikian hanya sedikit saja bangunan kuno yang terawat di Kota Semarang, hal ini menunjukkan kurang seriusnya Pemerintah Kota Semarang mengurus kota.

Adapun kawasan bersejarah di Kota Semarang yang kiranya layak didahulukan untuk dikonservasi adalah Kawasan Kota Lama, Kawasan Kampung Kauman dan Pasar Johar, Kawasan Kampung Pecinan dan Pekojan, serta Kawasan Kampung Sekayu. Kawasan-kawasan ini merupakan kawasan bersejarah yang harus dilestarikan, artinya bahwa bangunan ataupun feature bersejarah yang ada di kawasan ini harus dilindungi, dan dikembangkan sejauh bersinergi dan tidak bertentangan dengan prinsipprinsip konservasi cagar budaya. Pariwisata dan kegiatan entertainment terbatas cocok untuk pengembangan kawasan ini agar kawasan dapat menghidupi dan merawat dirinya sendiri, dan sebagai contoh adalah restoran Ikan Bakar Cianjur dan Gereja Blendhuk yang telah diuraikan di atas.

\section{Metode Penelitian}

Penelitian dititikberatkan pada studi historis, arkeologis dan antropologis terhadap Kawasan lama di Kota Semarang, antara lain Kawasan Kota Lama, Kawasan Kampung Sekayu, Kawasan Kampung Kauman, Kawasan Pasar Johar (Kauman), Kawasan Pecinan dan Pekojan, yang akan ditetapkan sebagai kawasan konservasi. Studi historis dilakukan guna mengungkap sejarah dan peran kawasan tersebut di masa lalu, dengan menerapkan metode historis (heuristik, kritik, interpretasi dan sintese). Studi arkeologis dilakukan dengan mengadakan survei atas bangunanbangunan kuno dan fasilitas kuno lainnya, serta mengadakan klasifikasi atas kekunoan tersebut. Studi antropologis dilakukan dengan observasi dan wawancara terhadap komunitas yang tinggal di kawasan-kawasan tersebut guna melihat pola-pola hubungan sosial dan kelembagaan, sekaligus mengetahui pemanfaatan dan perawatan terhadap bangunan maupun fasilitas kunonya.
Data historis yang berupa dokumen, data arkeologis yang berupa bangunan kuno, maupun data antropologis yang berupa memori kolektif, baik berbentuk sumber primer maupun sekunder diklasifikasikan dan dianalisis secara deskriptif analitis. Hasil analisis ini dikaitkan pula dengan peraturan perundangan tentang Cagar Budaya yang berlaku, akan digunakan sebagai landasan bagi penetapan kawasan-kawasan konservasi, serta penyusunan konsep-konsep pelestarian, perlindungan, pengendalian dan pengembangan terhadap kawasan konservasi yang telah ditetapkan.

\section{Pembahasan}

\section{Kajian untuk Penetapan Kawasan Konservasi}

Dari hasil penelitian ditemukan nama-nama perkampungan-perkampungan kuno di Kota Semarang yang umumnya sekarang tinggal namanya saja untuk memberi nama kelurahan atau Rukun Warga (RW) atau nama jalan/gang. Walaupun perkampungan itu hanya tinggal namanya saja tetapi tetap perlu dilestarikan, sebab itu merupakan bagian yang memiliki nilai historis-kultural bagi Kota Semarang. Beberapa perkampungan tersebut sekarang masih ada yang memiliki beberapa rumah atau bangunan kuno, oleh karena itu perkampungan ini perlu ditetapkan sebagai kawasan konservasi bersama kawasan lainnya. Selain menyimpan bangunan-bangunan kuno, beberapa perkampungan lama tersebut juga masih menyimpan adat atau tradisi lama, atau sekedar memori kolektif misalnya yang berupa makanan atau masakan lama, atau dalam bentuk kesenian dan pakaian. Semuanya ini tentu saja akan lebih memantapkan atas kajian dan penetapan kawasan konservasi, sesuai dengan amanat Undang-Undang Nomor 11 Tahun 2010 tentang Cagar Budaya.

Adapun kriteria yang dipergunakan sebagai landasan pengkajian dan rencana penetapan kawasan konservasi di Kota Semarang ini, adalah kawasan atau perkampungan yang mengandung bangunan-bangunan cagar budaya atau bangunan yang berusia di atas 50 tahun. Hal ini berlandaskan pada Undang-Undang Nomor 11 Tahun 2010 tentang Cagar Budaya dan konsep-konsep pelestarian kebudayaan pada umumnya. Seperti halnya kota lama Semarang yang memiliki banyak bangunan kuno bersejarah, merujuk pada undang-undang tentang cagar budaya tersebut, maka kawasan kota lama ini layak 
ditetapkan sebagai kawasan konservasi atau kawasan situs pelestarian cagar budaya. Demikian halnya beberapa perkampungan yang ada di Kota Semarang yang memiliki lebih dari satu bangunan cagar budaya yang berusia lebih dari 50 tahun, maka layak diusulkan untuk ditetapkan sebagai kawasan konservasi. Ada sedikit perbedaan konsep antara kawasan konservasi dengan kawasan situs cagar budaya, yaitu untuk kawasan konservasi di samping memiliki bangunan-bangunan cagar budaya (tangible) di kawasan ini harus memiliki pula fenomenafenomena budaya lainnya (intangible), seperti seni, tradisi, memori kolektif dalam bentuk makanan atau pakaian dan sebagainya sehingga yang dimaksud dengan kawasan konservasi di sini merupakan kawasan peninggalan budaya yang lebih utuh, seperti konsep konservasi kawasan yang diartikan dalam Burra Charter.

Sejarah Semarang lama mencatat bahwa terdapat tempat-tempat yang menjadi pusat peradaban budaya yang saat ini masih eksis dan sebagian hanya tinggal kenangan (bangunan tua). Tempat tersebut dibagi menjadi 4 (empat) yaitu : Kampung Kauman, Kampung Pecinan, Kampung Belanda (Little Netherland), dan Kampung Melayu. Kampung Kauman pada tempo doeloe merupakan kawasan padat penduduk keturunan Jawa, sekarang keturunan Arab juga banyak. Kampung Pecinan dihuni sebagian besar oleh keturunan Tionghua dan Kampung Belanda merupakan daerah pemerintahan dan kota kecil yang sekarang disebut dengan Semarang Kota Lama. Sementara Kampung Melayu lebih banyak keturunan Arab, dan pada saat ini masyarakat Jawa lebih banyak berada di daerah Kampung Melayu.

Keempat kawasan tersebut dapat dijadikan sebagai kawasan konservasi. Melihat bentuk tata kota Semarang pada zaman sekarang, maka sebenarnya masih nampak sedikit berkumpulnya kawasan-kawasan lama di Semarang. Sebagai titik sentral adalah jembatan Kali Mberok, maka Kampung Melayu berada di sebelah utara yang terdapat jalan Layur dan Masjid Menara. Sementara Little Netherland berada di sebelah timur yang sekarang menjadi Kawasan Kota Lama dan berjajar gedung-gedung pemerintah Belanda ke arah barat hingga ke Bundaran Tugu Muda. Sementara di sebelah barat Kali Mberok merupakan kawasan Kauman. Masyarakat Tionghoa lebih banyak berkumpul di selatan Kali Mberok yang sekarang menjadi kawasan Pecinan.

\section{Kawasan Kauman}

Kauman atau Kampung Kauman secara legendaris merupakan kaum yang dihuni oleh masyarakat Jawa yang beragama Islam. Bangunan yang masih kokoh berdiri di kampung ini adalah Masjid Agung Kauman Semarang. Sebagai pusat peradaban Islam, maka Kauman sangat berperan penting dalam perkembangan Kota Semarang. Tidak hanya di Semarang, di Surakarta, Jogjakarta, Demak terdapat kampung Kauman. Karena pada era dulu, Kauman merupakan ciri khas perkampungan Jawa Islam. Ciri khas utama Kauman adalah adanya Masjid Besar, dengan Alun-alun, pusat pemerintahan keraton atau kabupaten dan pasar tradisional.

Kawasan Kauman Semarang muncul ketika Kerajaan Demak Bintoro berdiri sebagai kerajaan Islam pertama di Pulau Jawa. Nama Kauman sendiri berasal dari kata kaum sing aman (kaum = qoum = tempat tinggal orang Islam). Jadi Kauman bisa bermakna tempat tinggal masyarakat para pemuka Islam. Semarang diduga telah muncul pada sekitar abad 15, ditandai dengan menetapnya Ki Pandan Arang pada tahun 1398 Saka (Serat Kanda, hal. 310). Keberadaannya juga dicatat oleh Tome Pires yang dalam lawatannya ke daerah pesisir utara pulau Jawa sekitar tahun 1513 M mengunjungi beberapa kota di wilayah itu. Di antara kota-kota yang dikunjunginya ialah Camaram yang berpenduduk 3.000 orang (Cortesao, 1944:166) dan Camaram inilah yang diidentifikasi sebagai Semarang.

Ketika Kerajaan Demak Bintoro sudah berdiri, maka untuk mempersatukan Demak dengan wilayah sekitarnya perlu pejabat birokrasi pemerintahan yang bisa mengaturnya, salah satu tokoh yang memegang peran penting adalah Ki Ageng Pandan Arang I. Ki Ageng Pandan Arang merupakan putra dari Panembahan Sabrang Lor (Sultan Kedua dari Kesultanan Demak). Pada awalnya beliau babat alas (bubak) membuka hutan di suatu tempat yang sekarang bernama Kampung Bubakan. Dalam perkembangannya para pengganti Ki Ageng Pandan Arang I memindahkan pusat pemerintahan Semarang ke beberapa tempat, yaitu ke Kampung Gabahan, kemudian Kampung Sekayu dan terakhir ke Kauman-Kanjengan, sebelum dipindahkan lagi oleh Belanda ke kantor Balaikota Semarang yang sekarang ada di Jalan Pemuda. 
Setelah Ki Ageng Pandan Arang I wafat, maka posisi pemerintah diserahkan pada anaknya yang bermana Pangeran Mangkubumi (atau disebut juga Ki Ageng Pandanaran II - Sunan Bayat). Pada tahun 1695, kawasan Kota Lama Semarang dihuni oleh beragam etnis yang bertujuan untuk melakukan perdagangan dan ekspansi wilayah. Ekspansi wilayah dilakukan oleh orang-orang Eropa (Belanda) yang ikut berkembang di Kawasan Kota Lama. Pada masa itu, pemerintah Hindia Belanda membangun kawasan elit dan perkantoran yang berjajar dari Bundaran Bubakan hingga Bundaran Tugu Muda. Kemudian ada istilah yang membagi wilayah menjadi dua yaitu gedongan bagi kawasan elit Hindia Belanda dan perkampungan bagi warga pribumi. Kawasan perkampungan ini sekarang dikenal sebagai Kampung Pecinan, Kampung Melayu dan Kampung Kauman.

Usulan penetapan kawasan konservasi atau kawasan cagar budaya terhadap Kampung Kauman, dilatarbelakangi keberadaan Masjid Besar Kauman dan peninggalan bangunan kuno yang dapat dikategorikan sebagai cagar budaya seperti Pasar Johar dan beberapa bangunan kuno rumah penduduk.

Mengenai Masjid Agung Kauman Semarang, menurut tradisi Semarang, pada masa pemerintahan Adipati Surohadimenggolo II, ketika pecah Perang Cina tahun 1741 Masjid Pedamaran musnah terbakar (Anonim, 1988:5). Nampaknya kehancuran masjid diperkirakan baru terjadi pada tahun-tahun berikutnya, mengingat legenda masjid masih muncul dalam peta tahun 1741. Untuk mengganti Masjid Pedamaran yang rusak, kemudian dibangun masjid baru yang ditempatkan di sebelah barat alun-alun Semarang, yang kini dikenal sebagai Masjid Agung Kauman.

Dua inskripsi yang tertempel di dinding sisi dalam pintu gerbang masjid menunjukkan tentang pendirian dan peresmian Masjid Agung Kauman. Inskripsi berbahasa Jawa huruf Jawa berbunyi sebagai berikut :

"Pemut kala panjennengngane

kanjeng tuwan nikolas

harting hedelir gopennar sarta

(d) rektur hing tanah jawi gennipun

kangjeng kyahi dipati suradimagala

hayasa sahega dadosse

masjid puniki

\section{kala bijrat 1170"}

Adapun terjemahan bebasnya adalah : "Sebagai peringatan ketika Kanjeng Tuwan Nikaolas Harting, yang mulia Gupernur dan Direktur Tanah Jawa pada saat Kanjeng Kyahi Adipati Surahadimenggala membangun hingga selesainya masjid ini pada tahun 1170 Hijrah.

Inskripsi kedua yang berbahasa Belanda dan huruf latin, berbunyi sebagai berikut :

“ANNO 1756

Ter gedagtenis

Omdet de tegeering va $u$

HEERE

Nicolaas Hartingh

Raad extra-ordin' van Neer

lands INDIA, mitsgaders

Gouv \&o Direct van Ia

va, is deze TEMPES

volbouwt door de Ade

pattij Soeradiman

i.gala"

Terjemahan bebasnya adalah : "Anno 1756, Kenangan kepada Yang Terhormat (Ayah) Nicolaas Hartingh, Penasehat Luar Biasa Nederland Hindia, Gupernur dan Direktur Jawa oleh sebab diresmikannya masjid oleh Adipati Soeradimanggala"

Kedua inskripsi itu jelas membuktikan bahwa Masjid Besar Kauman diresmikan pada tahun 1170 Hijrah atau 1756 Masehi. Masjid dibangun dan diresmikan oleh Adipati Semarang Surohadimenggala, pada masa Gupernur dan Direktur Jawa Nicolaas Hartingh.

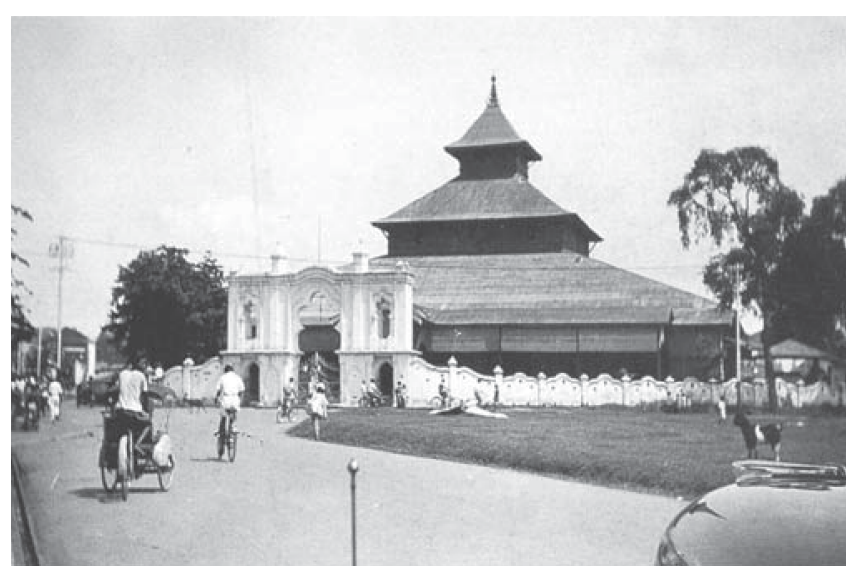

Keunikan Masjid Agung Kauman Semarang di masa lampau 
Di kawasan Kauman ini terdapat pula Pasar Johar dan Alun-alun. Tentang Pasar Johar, bahwa pada awal abad ke-18, Kota Semarang sudah menunjukkan kehidupan perdagangan yang ramai ditandai dengan keberadaan pasar dan pedagang-pedagang dari berbagai bangsa. Pasar yang dicatat oleh François Valentijn di atas adalah cikal bakal Pasar Johar, karena memang ia merekam situasi di lingkungan pusat Kota Semarang pada waktu itu. Semula, pasar yang berlokasi di depan dan sebelah timur rumah bupati itu hanya berbentuk kios-kios dan los-los. Di pasar ini dijual berbagai komoditi seperti kain, barangbarang kelontong, bahan-bahan pangan, dan lain-lain. Pada tahun 1898 - 1900, pemerintah kolonial Belanda membangun Pasar Johar dengan dana yang ditarik dari 240 pedagang sebesar $\mathrm{f}$. 75 per orang dan bantuan pemerintah sebanyak f. 18.000,-. Para pedagang masih diharuskan untuk membuat sekat-sekat sendiri. Pada tahun 1917, gemeente (kota praja) Semarang mulai menaikkan retribusi dari para pedagang sebagai konsekuensi penggunaan tanah milik gemeente itu. Pada tahun 1920, para pedagang minta kepada pemerintah gemeente untuk membangun

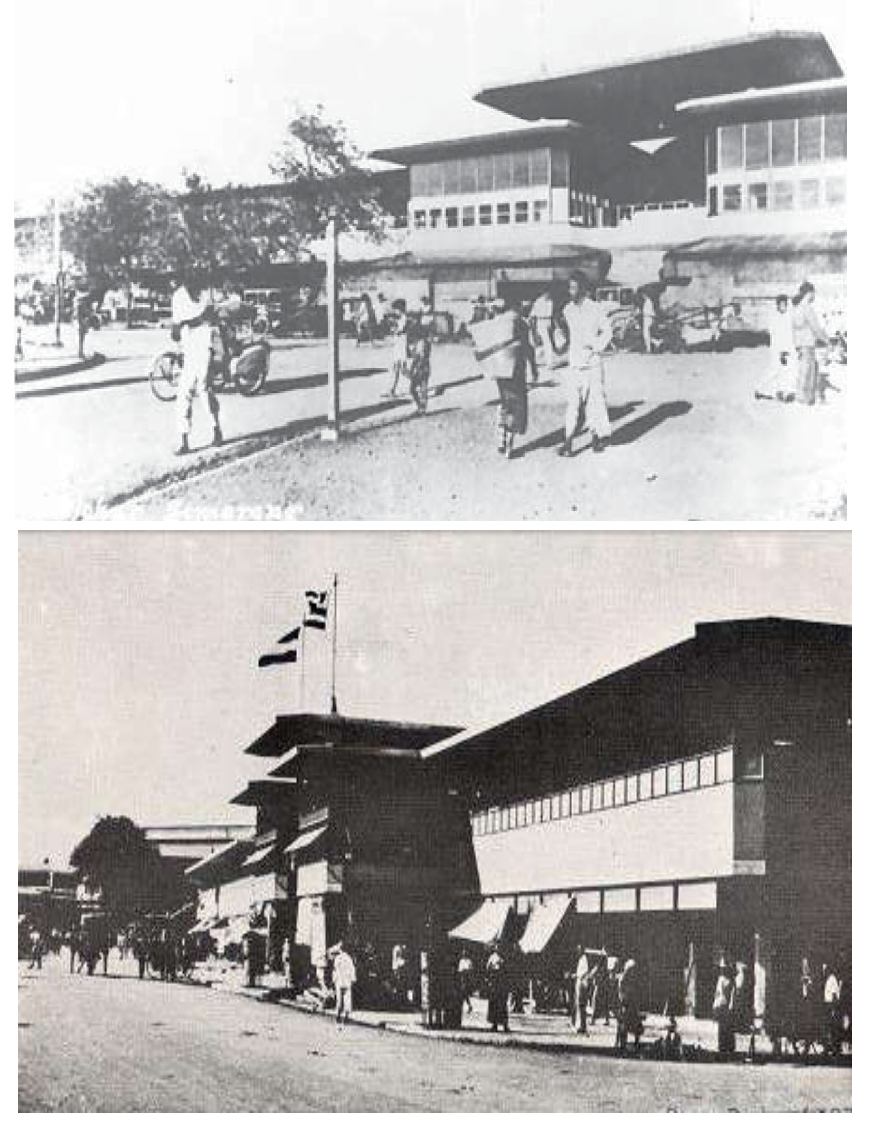

Keunikan Pasar Johar Semarang di masa lampau tembok keliling bagi Pasar Johar dan membangun loslos yang berpintu. Setelah pembangunan itu, retribusi dinaikkan untuk menutup biaya yang telah dikeluarkan oleh gemeente (Gedenkboek der Gemeente Semarang 1906-1931: 182). Selanjutnya pada tahun 1938 Pasar Johar dibangun lagi dan pembangunannya dipercayakan kepada seorang arsitek terkenal, Thomas Karsten. Arsitek ini telah membuat desain Pasar Johar dengan memperhatikan faktor pencahayaan, ventilasi, dan tata ruang, sehingga dapat memberi kenyamanan bagi orang yang berada di dalamnya.

Pasar Johar, yang sudah tercatat oleh Valentijn pada awal abad ke-18 dapat dikategorikan sebagai warisan budaya yang memiliki nilai tradisi tinggi, karena telah menempuh waktu dan berfungsi dalam waktu ratusan tahun. Pasar Johar adalah built heritage, warisan sejarah dan seni arsitektur, yang telah menjadi landmark dan identitas Kota Semarang sejak ratusan tahun silam oleh karena itu pasar ini sangat berpotensi untuk dikembangkan dengan wawasan wisata budaya. Kondisi saat ini Pasar Johar baru saja terbakar, tentu harus direstorasi karena merupakan cagar budaya.

\section{Kampung Pecinan}

Pada awalnya orang Tionghoa bertempat di Kota Lama dan sekitar Kuil Sam Po Kong namun pada tahun 1695 pemerintah Hindia Belanda secara tidak langsung membatasi akses masyarakat Tionghoa hingga akhirnya dipindah ke sekitar kawasan Kampung Pecinan. Hal ini dilakukan karena dampak dari peristiwa Geger Pacinan yang dimulai di Jakarta dan meluas hingga Jawa Tengah. Perkembangan masyarakat Tionghoa semakin banyak dan kemudian mendirikan kawasan serta rumah-rumah sendiri yang dibuat dengan atap genting dan pagar-pagar tinggi. Rumah-rumah masyarakat Tionghoa pertama kali berada di sekitar Pecinan Lor dan Wetan. Karena membutuhkan biaya tinggi dan berbagai syarat yang tidak mudah dalam mendirikan rumah, maka ketika itu hanya orang-orang Tionghoa yang kaya saja yang bisa membangun rumah.

Kondisi jalan yang tidak terlalu lebar seperti sekarang, membuat masyarakat Tionghoa menciptakan sebuah moda transportasi dengan memakai tenaga kuda yang disebut dengan Be Too. Masyarakat Tionghoa lebih banyak melakukan aktivitas perdagangan yang berasal 
dari Cina (Tiongkok) seperti perhiasan, sutra, keramik dan lain sebagainya. Hingga sekarang, perdangangan tersebut masih dilakukan di kawasan Pecinan, misalnya di kawasan perdagangan perhiasan dan kain yang berada di Jalan Wahid Hasyim. Poin yang menjadi titik kebangkitan orang Tionghoa di Semarang adalah ketika Pemerintah Hindia Belanda mulai mendekati orang-orang Tionghoa yang sukses. Salah satunya dengan mengangkat orang Tionghoa menjadi pejabat di kantor-kantor pemerintah Hindia Belanda. Kwee Kiau Loo adalah orang Tionghoa pertama yang menjadi pejabat Hindia Belanda.

Pengangkatan orang Tionghoa menjadi pejabat tidak berlangsung lama, ketika Semarang secara de yure diserahkan kepada Pemerintah Hindia Belanda oleh VOC, maka keberadaan masyarakat Tionghoa sedikit bergoyah. Salah satunya dengan memberikan pajak tinggi terhadap barang dagangan yang dikelola oleh orang Tionghoa seperti arak dan garam. Walapun begitu, pajak yang dikenakan justru merupakan sumbangan tinggi bagi keberadaan Semarang pada masa lalu. Dalam bidang perdagangan, orang Tionghoa di Semarang memiliki peranan yang besar karena adanya pendapatan masuk ke kas pemerintah Hindia Belanda dari faktor pajak dan
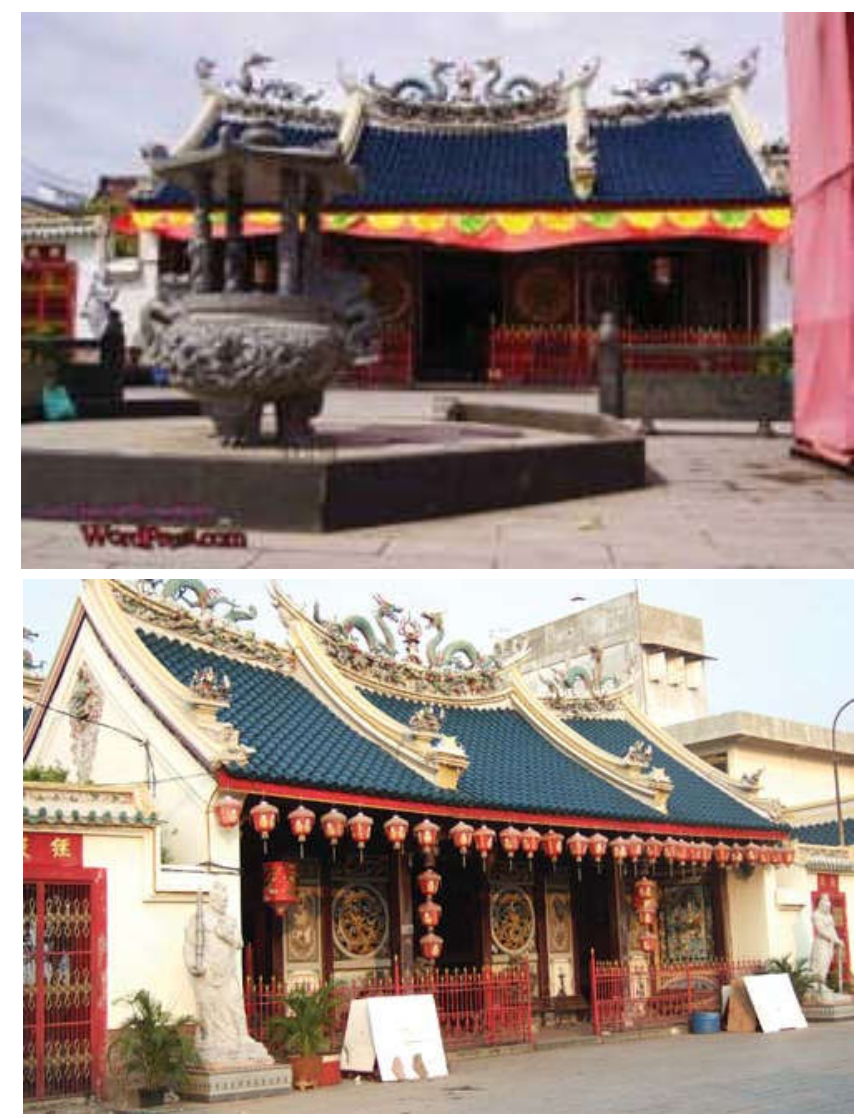

Kelenteng Tay Kak Sie di Gang Lombok Semarang cukai.

Pada masa itu, banyak orang Tionghoa yang menjadi syahbandar (pemungut pajak) karena memang, perdagangan ekspor dan impor dilakukan dengan jalur laut pelabuhan Semarang. Sampai sekarang penamaan bandar bisa di temukan di sekitar kawasan Pecinan yang bernama Jalan Sebandaran. Selain berperan dalam pendapatan dari cukai dan pajak, orang Tionghoa juga berperan dalam mendirikan beberapa pabrik kecil yang dapat menjadi tempat mata pencaharian penduduk lain.

Kelenteng Tay Kak Sie merupakan bangunan pemujaan yang didirikan di kawasan Pecinan pemukiman etnis Tionghoa. Kelenteng ini merupakan salah satu unsur kawasan Pecinan yang ada di Indonesia, didirikan tahun 1746 oleh Kho Ping dan Tan Lik diberi nama Kwam Im Ting yang berarti untuk pemujaan Dewi Kwan Im di tengah Gang Belakang. Pada tahun 1771 kelenteng ini dipindah ke Gang Lombok dan diberi nama Tay Kak Sie yang berarti Kuil Kesadaran Agung. Kelenteng ini mengalami beberapa kali pemugaran besar yaitu tahun 1845, 1890 dan 1956. Masyarakat Semarang percaya keberadaan kelenteng ini menunjang kemakmuran, kesejahteraan serta menghindarkan berbagai musibah bagi penduduk sekitarnya. Sebagai tempat ibadah kondisi kelenteng saat ini cukup terawat. Selain umatnya, kelenteng ini banyak dikunjungi oleh wisatawan, sebab sangat unik dan bernilai historis.

\section{Kawasan Kota Lama (Kampung Eropa)}

Kampung Eropa merupakan sebutan untuk wilayah yang dihuni oleh orang-orang Belanda. Kawasan yang lebih umum disebut dengan Kota Lama Semarang ini mulai berkembang pada tahun 1741. Pada awal mula, kawasan Eropa ini hanya berupa gedung perkantoran dan gudang namun kemudian berkembang menjadi pusat budaya dan perdagangan dengan banyaknya bermunculan hotel, perumahan elit dan beberapa bangunan lain. Ciri mendasar dari sebuah Kampung Eropa adalah desain gedung dengan arsitektur model art deco. Orang Belanda yang bermukim di Semarang tidaklah sebanyak orang Tionghoa, namun mereka menguasai segala akses pemerintahan dan perdagangan sehingga lebih mudah melakukan pertukaran budaya.

Banyak sekali bangunan kuno yang ada di kawasan Kota Lama Semarang dan sekarang satu- 
persatu mulai dipugar dan dikonservasi baik dilakukan oleh pemerintah pusat maupun pemerintah Kota Semarang dan masyarakat. Dengan adanya Kota Lama dan bangunan-bangunan kuno lainnya yang ditemukan di Kota Semarang, maka pemerintah pusat melalui Kementerian Pekerjaan Umum menetapkan Kota Semarang sebagai salah satu dari sepuluh Kota Pusaka di Indonesia. Predikat ini akhirnya juga mendorong para pelestari kota kuno untuk memasukkan kawasan Kota Lama Semarang dalam daftar Warisan Dunia di UNESCO dengan berbagai persyaratan yang ditentukan. Beberapa bangunan kuno di kawasan Kota Lama antara lain Stasiun Tawang, Gereja Blenduk, Gedung Marba, Gedung Spiegel, Gereja Gedangan, Gedung Ikan Bakar Cianjur, Gedung Marabunta, dan lain-lain.

Stasiun Tawangmerupakan stasiun kereta api yang masih digunakan sampai saat ini, merupakan pengganti stasiun Tambak Sari milik NIS yang pertama. Setelah diresmikan pada tanggal 16 Juni 1864 untuk melayani jalur Semarang-Jogja-Solo. Stasiun ini merupakan salah satu komponen penting dalam pengangkutan barang maupun penumpang pada saat itu. Selanjutnya stasiun ini dapat menunjukkan bukti perjalan sejarah bidang transportasi pada masa era kolonial.

Hingga saat ini Stasiun Tawang Semarang masih berfungsi baik sebagai stasiun kereta api yang melayani route Jakarta-Semarang-Surabaya. Tidak

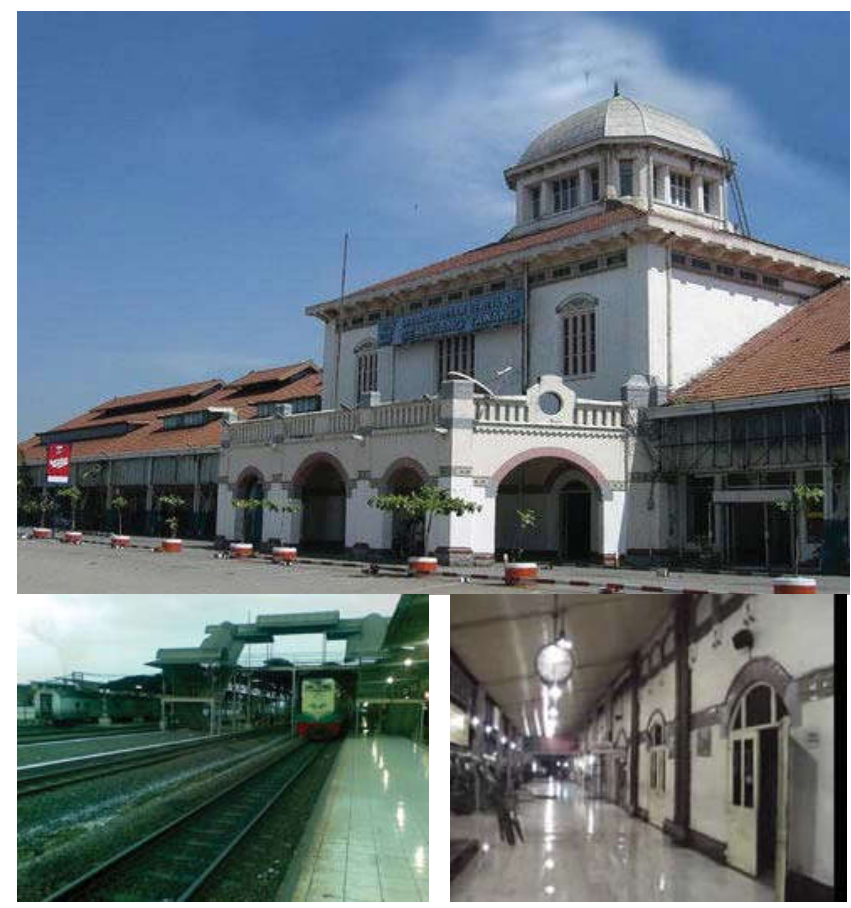

Stasiun Tawang Semarang

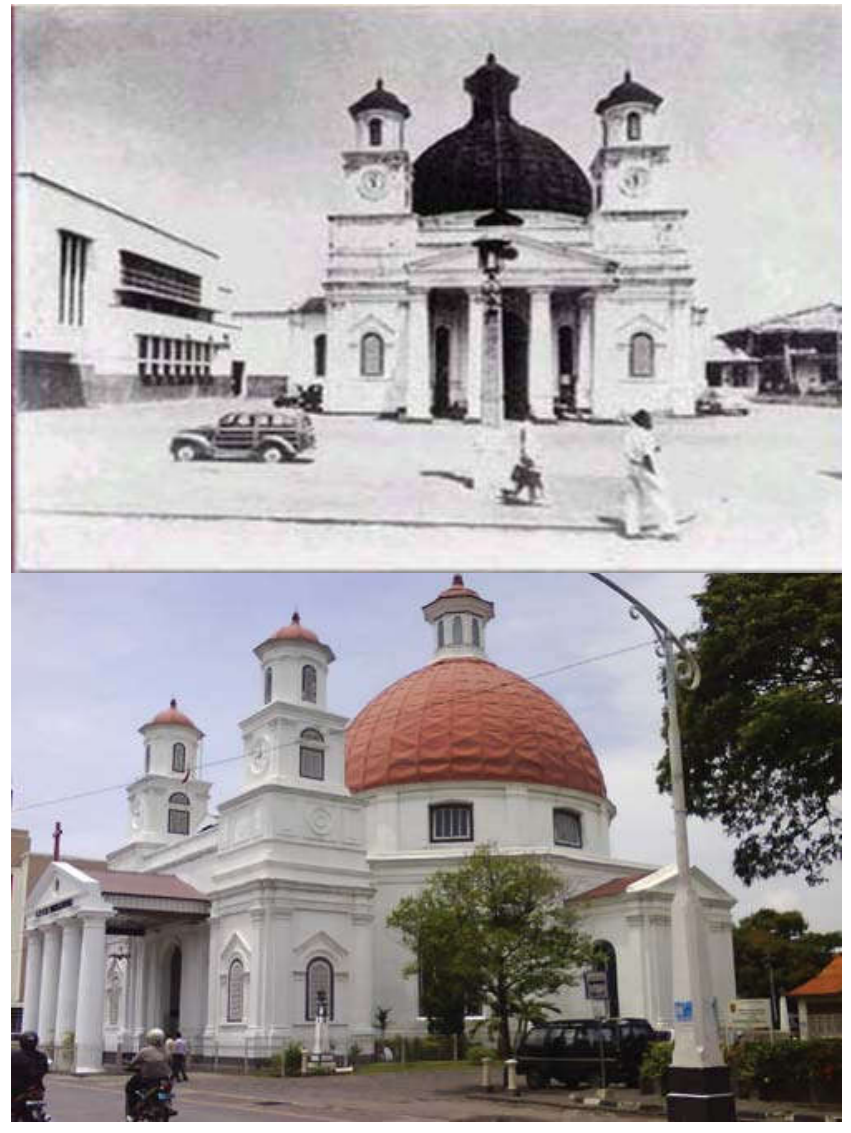

Gereja Blenduk Semarang

terlihat wisatawan khusus mendatangi bangunan ini, tetapi para penumpang yang turun dan naik cukup menikmati keunikan bangunan. Sentuhan pariwisata terhadap Stasiun Tawang supaya perlu lebih ditingkatkan lagi agar bangunan ini lebih cantik dipandang mata dan mengundang wisatawan.

Gereja Blenduk (GPIB Immanuel) didirikan pada tahun 1742. Pada tahun 1894-1895 bangunan gereja diperbaharui oleh HPA de Wilde dan W. Westmaas. Gereja Blenduk memiliki gaya arsitektur Eropa dengan denah segi delapan beraturan (oktagonal) dengan penampil di sisi barat, utara, timur, dan selatan membentuk salib Yunani dengan gaya arsitektur Pseudo Baroch. Atap bangunan berbentuk kubah serupa dengan bangunan kubah di Eropa. Gereja Blenduk ini telah ditetapkan sebagai BCB dengan Peraturan Menteri Kebudayaan dan Pariwisata No. PM.24/PW.007/MKP/2007.

Kondisi gereja ini cukup terawat dan digunakan sebagai tempat ibadah umat Kristiani di Kota Semarang. Dinas Kebudayaan dan Pariwisata Kota Semarang mestinya membuat paket wisata Kota Semarang, termasuk kunjungan terhadap gereja ini. 


\section{Kawasan Tugu Muda}

Tugu Muda adalah sebuah monument yang didirikan untuk memperingati pertempuran lima hari yang pernah terjadi di Semarang pada tahun 1945. Kawasan ini sebenarnya merupakan kawasan lama yang dibangun oleh pemerintah kolonial Belanda yang sering disebut sebagai Kawasan Bojong. Saat ini beberapa bangunan kuno yang dapat diusulkan ditetapkan sebagai bangunan cagar budaya, antara lain Gedung Lawang Sewu, Gereja Katedral, Wisma Perdamaian dan Kompleks Balaikota Semarang.

Lawang Sewu dibangun pada abad XIX oleh arsitek C. Citroen. Bangunan ini diberi nama Lawang Sewu karena memiliki banyak pintu. Kompleks Lawang Sewu terdiri atas 2 massa bangunan utama: di sebelah barat berbentuk L dan di sebelah timur merupakan massa linier. Semua bangunan berlantai 2 dan bergaya Romanesque Revival. Pondasi yang digunakan adalah batu, struktur, dan dinding bata. Daerah pintu masuk diapit oleh 2 menara yang bagian atasnya membentuk copula persegi

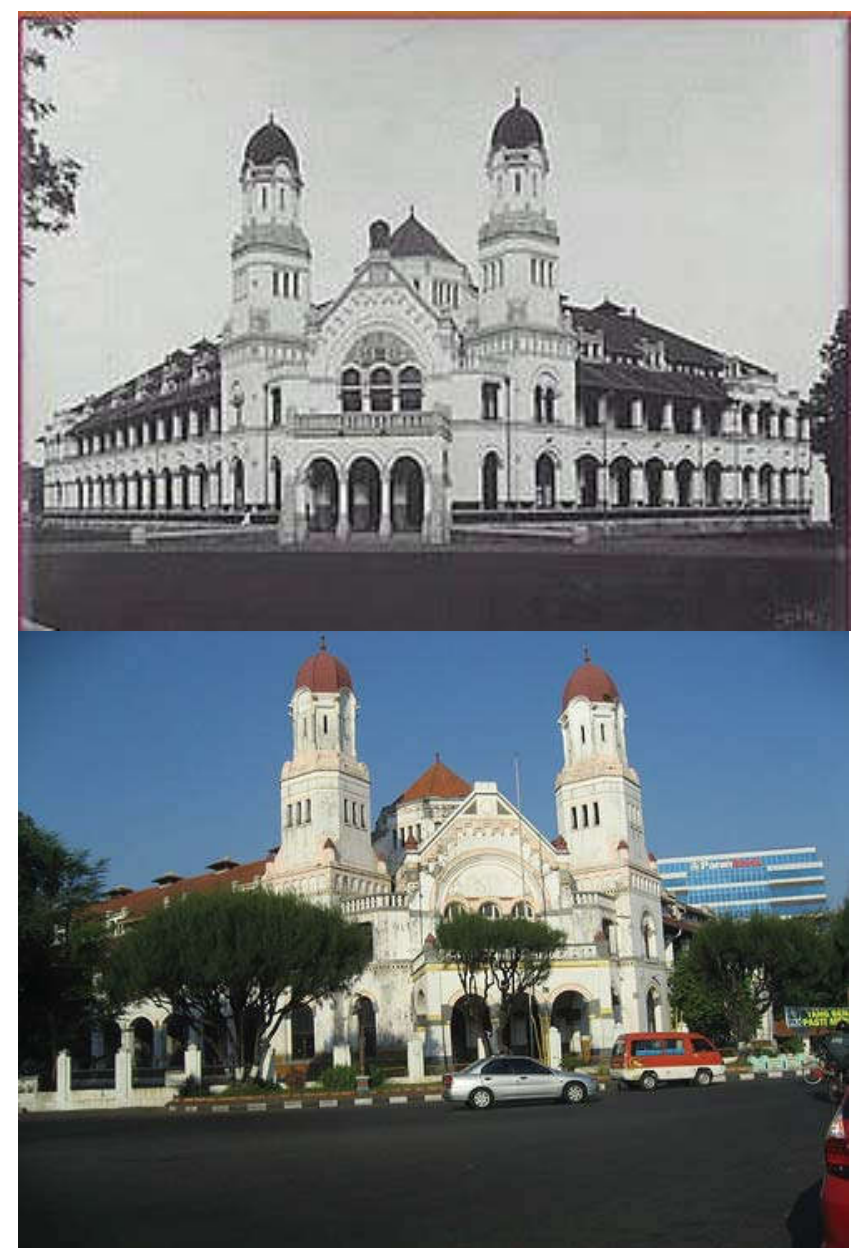

Gedung Lawang Sewu dulu dan kini

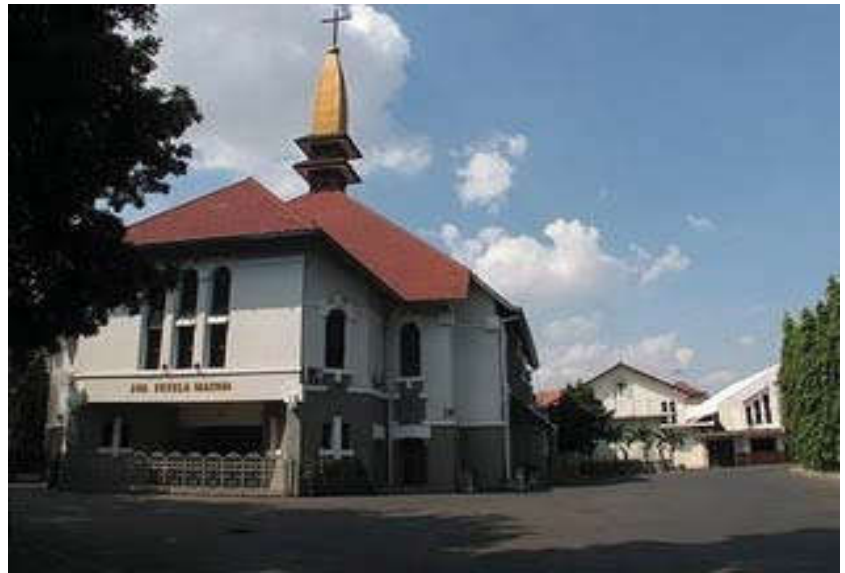

Gereja Katedral Semarang

delapan bertudung kubah. Bentuk atap limasan majemuk ditutup dengan genteng. Pintu memiliki daun ganda dan terbuat dari kayu. Ambang atas jendela berbentuk lengkung dan ambang bawahnya tidak disangga. Tipe jendela adalah jendela ganda dengan krepyak.

Gedung Lawang Sewu saat ini sudah direnovasi oleh pemiliknya, yaitu PT KAI. Bangunan ini memang sangat unik dan menarik, maka banyak dikunjungi wisatawan dan menjadi ikon Kota Semarang. Setelah direnovasi, diharapkan Gedung Lawang Sewu tetap dimanfaatkan secara terbuka dan dapat diakses oleh masyarakat umum, sebab merupakan ikon dan kebanggaan masyarakat Semarang.

Bangunan Gereja Katedral berciri arsitektur kolonial dan digunakan sebagai rumah ibadah. Di atas bangunan perantara terdapat menara lonceng. Bangunan ini terkait dengan paroki dari Vicariat Apostolik Jakarta. Gereja Katedral sekitar tahun 1927 menjadi salah satu gereja stasi dari paroki Semarang. Pada tanggal 26 Januari 1927 Gedung yang semula dipakai Dinas Kesehatan "Diens Voor Volksgezondheid" ini, kemudian dipugar dan direnovasi menjadi sebuah gereja pada tanggal 9 Oktober 1927.

Kondisi gereja ini cukup terawat dan digunakan sebagai tempat ibadah umat Katolik di kota Semarang. Dinas Kebudayaan dan Pariwisata Kota Semarang mestinya membuat paket wisata Kota Semarang, termasuk kunjungan terhadap gereja ini.

\section{Kawasan Kampung Sekayu}

Kampung Sekayu adalah kampung yang bersejarah di Kota Semarang, merupakan pusat pemerintahan Kabupaten Semarang sebelum 
dipindahkan ke Kampung Kauman sekarang. Di samping itu di Kampung Sekayu sampai saat ini banyak ditemukan rumah-rumah tinggal yang kuno berarsitektur Indis, yaitu arsitektur bergaya campuran Jawa dan kolonial Belanda. Sebuah masjid kuno juga dijumpai di kampung ini, berarsitektur "Jawa Masjidan" atau sering disebut pula "tajug tumpang sari” dengan tiang tunggal (soko tunggal) yang menyangga atap tumpang. Sayangnya masjid ini sekarang sudah diubah oleh masyarakat menjadi masjid modern. Kondisi Kampung Sekayu yang bersejarah dan sangat unik ini mestinya harus dilindungi oleh Pemerintah Kota Semarang, sebab apabila kampung ini hilang, maka Kota Semarang akan semakin kehilangan aspek historisnya yang cukup penting bagi eksistensi kota ini ke depan.

Dari catatan Soekirno (1956) diketahui bahwa pada tahun 1659 pemerintahan Kabupaten Semarang dipegang oleh Mas Tumenggung Wongsorejo yang bukan trah Pandan Arang dan kabupatennya dipindahkan dari Bubakan ke kampung Gabahan. Dari pelacakan di Kampung Gabahan, di sana ternyata tidak dijumpai toponim yang mengarah ke unsur pembentuk struktur kota. Yang ada ialah toponim Sebandaran (bandar: pelabuhan sungai) dan Jagalan (tempat jagal) yang bukan profesi pemerintahan. Toponim lain adalah Seong yaitu Seong Gedangan (bekas kebun pisang), Seong Kulbandang (bekas kebun Kulbandang), dan Seong Kuda (bekas kandang kuda) yang lebih bernuansa Cina.

Seperti diketahui bahwa dari Gabahan, kabupaten kemudian dipindahkan ke Kampung Sekayu. Di kampung ini terdapat toponim seperti Sekayu Tumenggungan, Sekayu Kepatihan dan Basahan yang berkaitan dengan profesi pemerintahan, serta Sekayu Mesjid yang semuanya berkaitan dengan unsur pembentuk struktur kota. Ditambah lagi adanya toponim Bedagan (bebedag), yang artinya tempat berburu juga mendukung asumsi itu, karena berburu bagi bangsawan Jawa merupakan satu rekreasi tersendiri, yang di daerah Mataram (Surakarta dan Yogyakarta) tempat itu lazim disebut Krapyak.

Bertolak dari adanya toponim yang mengacu ke profesi pemerintahan dan juga melihat tata ruang kawasan, orang bisa menduga bahwa Sekayu pernah memiliki fungsi khusus dalam sejarah kota Semarang, diperkirakan hal itu terjadi antara tahun 1666-1670. Ketika pusat pemerintahan ada di Sekayu, pertumbuhan kota Semarang tidak lagi terkonsentrasi di kawasan timur, tetapi mulai bergeser ke arah barat. Jalur jalan mulai Gang Warung di sisi timur Kranggan-Depok hingga Sekayu di sisi barat merupakan jalan utama. Permukiman pribumi tidak lagi terbatas di sekitar Kauman, Pedamaran dan Gendingan tetapi meluas ke sekitar Sekayu yang waktu itu merupakan pusat bongkar muat kayu dari perahu di Kali Garang.

Kapan pusat pemerintahan (Dalem Kanjengan) pindah dari Sekayu ke tempat lain tidak diketahui dengan pasti. Baru pada seperempat abad kemudian muncul bukti baru, yaitu peta "PAAN van het Fort en omleggende Cituatie van Samarangh". Dalam peta tahun 1695 itu ternyata Dalem Kanjengan sudah berada di Kauman. Kapan tepatnya Dalem Kanjengan pindah juga tidak jelas, diperkirakan terjadi antara tahun 1670 hingga 1695. Kemudian apakah kepindahan itu langsung dari Sekayu ke Kauman, ataukah ada masa interegnum di tempat yang lain, semuanya masih menjadi tanda tanya.

Dengan pindahnya Dalem Kanjengan ke Kauman, berarti pusat pemerintahan kota Semarang bergeser kembali ke timur, dan kepindahan itu sekaligus menandai kembalinya otoritas politik atas kota Semarang pada dinasti Pandan Arang. Peta tahun 1695 menunjukkan bahwa hingga akhir abad 17 struktur Kota Semarang tetap belum menunjukkan ciri sebagai kota Islam yang sesungguhnya. Komposisi tata ruang kota baru berubah dan menunjukkan ciri fisik dan morfologi kota Islam setelah tahun 1750, yaitu dengan pindahnya mesjid dari Pedamaran ke Mesjid Besar Kauman yang letaknya ada di sebelah barat alun-alun. Pada era ini pusat kota berada di sekitar Kampung Kauman, lengkap dengan adanya Dalem Kanjengan, alun-alun, mesjid, dan pasar yang dikelilingi oleh pejabat birokrasi, profesi, dan etnik yang tinggal di Kampung Kranggan, Gendingan, Padepokan, Pedamaran, Pecinan, Pekojan, dan lain-lain.

\section{Pemanfaatan Kawasan Konservasi untuk Identitas Budaya dan Pariwisata}

Tepat sekali bila perkampungan menjadi salah satu identitas kota, sebab mengandung unsur-unsur historis tradisional dan harus dilestarikan sebagai bagian dari sejarah Kota Semarang. Di samping itu perkampungan telah menjadi bagian dari simbol-simbol Kota Semarang, oleh karena itu akan relevan sekali digunakan sebagai 
identitas budaya kota.

Menurut kamus Bahasa Indonesia, pengertian identitas adalah ciri-ciri, jati diri atau tanda-tanda yang khas pada orang atau benda. Apabila dikaitkan dengan pengertian dalam sebuah sistem atau struktur, maka identitas adalah untuk menandai adanya perbedaan peran dan kedudukan pada bagian atau elemen-elemen sistem tersebut. Keesing (1989) menyebutkan bahwa hubungan antar elemen dalam suatu sistem sosial adalah hubungan identitas. Identitas itu adalah tanda untuk memberi ciri khas yang membedakan dengan hal lainnya. Oleh karena tanda mempunyai sifat khas, maka identitas adalah sebuah simbol yang dapat menunjukkan kekhasannya dan batasan peran yang melekat pada individu atau kelompok sosial. Hal ini memang sesuai dengan sifatsifat hubungan dari simbol yang arbitrary. Menurut James P. Spradley (1972: 11-18), tanda paling tidak memiliki tiga aspek yaitu indeks, icon dan simbol. Icon adalah suatu tanda yang memiliki hubungan bersifat formal (formalassociation), indeks adalah suatu tanda yang memiliki hubungan alamiah (natural-association), sedangkan simbol adalah suatu tanda yang memiliki hubungan semaunya (arbitrary-association) dengan obyeknya. Dengan sifatnya yang khas maka simbol-simbol yang dimiliki oleh suatu kelompok individu akan menjadi tanda atau identitas yang khas bagi pemiliknya. Oleh karena itu, hubungan identitas dari elemen-elemen suatu struktur sosial pada dasarnya juga merupakan hubungan-hubungan simbolik. Dalam hal ini dimaksudkan bahwa identitas itu menjembatani hubungan-hubungan antar elemen. Suatu kelompok sosial atau masyarakat yang sedang mencari identitas, akan mengintensifkan hubungan-hubungan dengan masyarakat lainnya sebagai elemen-elemen dari suatu struktur masyarakat yang lebih luas.

Dari uraian di atas tampak bahwa identitas mengandung simbol-simbol untuk menunjukkan kekhasannya. Suatu lembaga, organisasi atau sekelompok orang yang membentuk grup atau masyarakat, untuk integrasi dan mengikat anggota-anggotanya sering menggunakan simbol-simbol. Simbol-simbol biasanya berisi atau mencerminkan unsur-unsur yang terkandung di dalam lembaga atau sekelompok orang itu yang merujuk ke sejarah, sifat atau pun harapan dari lembaga atau masyarakat yang bersangkutan. Dalam kaitannya dengan Kota Semarang, kota merupakan tempat tinggal dan tempat berkehidupan sekelompok orang atau masyarakat yang berdomisili di kota ini. Dalam sebuah kehidupan berkelompok atau bermasyarakat, maka dibutuhkan simbol-simbol sosial untuk berintegrasi bagi anggota masyarakat. Salah satu simbol yang digunakan diambil dari peristiwa sejarah masyarakat yang bersangkutan, untuk memberikan identitas yang berbeda dengan masyarakat lainnya dalam suatu pemikiran struktural fungsional. Perbedaan-perbedaan inilah merupakan salah satu unsur yang sering dicari manusia untuk menunjukkan identitas dan kedudukannya, dan biasanya dicari dari sejarah atau masa lalunya. Perkampungan-perkampungan di Kota Semarang memang bernilai sejarah, sehingga menunjukkan satu point bila akan digunakan sebagai simbol atau identitas masyarakat Semarang. Namun demikian supaya perkampungan ini dapat digunakan sebagai identitas budaya kota dan masyarakat Semarang, maka masih harus ditata kembali, diintegrasikan dengan program perencanaan tata ruang kota.

Perkampungan di Kota Semarang itu memiliki akar sejarah dan budaya, yang muncul bersamaan dengan terbentuknya Kota Semarang secara tradisional di masa lampau. Secara teoritis tradisi itu sendiri adalah bagian dari suatu kebudayaan masyarakat yang cukup penting peranannya, karena fungsi dari tradisi mengandung suatu identitas sosial komunitas. Edward Shils menganggap bahwa tradisi biasanya memiliki muatan ideologis yang mengacu pada masa lalu melalui proses intepretasi. Hal ini dibenarkan pula oleh Handler dan Linnekin bahwa tindakan yang bersifat tradisional biasanya mengacu pada masa lalu pada suatu hubungan yang bersifat simbolik dan biasanya dicirikan dengan adanya kontinyuitas maupun diskontinyuitas. A.L.Krober mendefinisikan tradisi sebagai suatu pewarisan unsurunsur budaya secara internal yang menembus waktu (Handler and Linnekin, 1984: 273290).

Karena perkampungan di Kota Semarang itu terbentuk secara historis tradisional, maka dapat dijadikan identitas sosial budaya masyarakat Kota Semarang. Pengertian identitas sebetulnya adalah pengertian simbolik, artinya bahwa identitas itu mengandung unsurunsur simbolis yang bersifat arbitrary, yang membedakan dengan identitas lainnya. Dalam hubungan integratif, secara struktural fungsional, untuk pembedaan inilah biasanya masyarakat akan menciptakan simbol- 
simbolnya yang diambilkan dari sejarah masa lalunya yang diintegrasikan dengan simbol-simbol barunya.

Pencanangan Kota Semarang sebagai salah satu kota pusaka di antara 10 kota pusaka di Indonesia oleh Kementerian Pekerjaan Umum baru-baru ini, hal ini menunjukkan Kota Semarang merupakan salah satu kota unik dan dianggap memiliki nilai sejarah dan budaya yang cukup tinggi bagi bangsa dan negara. Munculnya ide untuk memasukkan Kota Lama Semarang dalam daftar 'World Heritage', hal ini juga atas keunikan kota ini. Selain untuk melestarikan budaya kebendaan, maka di kawasan konservasi juga harus dikembangkan budaya lokal yang tidak bersifat kebendaan, misalnya festival kota lama yang diisi dengan penampilan budaya khas Semarang baik melalui tradisi kuliner maupun tradisi yang lainnya.

Adapun kaitan antara perkampungan dengan dunia kepariwisataan memang secara langsung tidak ada, sebab secara visual tidak tampak, kalaupun tampak hanya berupa tulisan di jalan-jalan, di gang-gang dan di papan nama yang tentunya jauh dari keindahan dan keunikan secara visual. Karena itu sebenarnya untuk dapat mengkaitkan antara perkampungan dengan kegiatan kepariwisataan di Semarang, maka beberapa perkampungan dikaji dan ditetapkan sebagai kawasan konservasi dan dikelola sesuai dengan amanat undangundang tentang cagar budaya dan undang-undang kepariwisataan. Beberapa perkampungan saat ini memang sudah dikembangkan pemerintah Kota Semarang untuk kegiatan kepariwisataan, seperti Kampung Pecinan dengan kegiatan Kampung Semawis, Kampung Batik sebagai pusat batik Semarangan, juga kegiatan festival Kota Lama Semarang, semua ini merupakan manifestasi dari pengembangan kawasan konservasi.

Dengan ditetapkannya sebagai kawasan konservasi atas beberapa perkampungan di Kota Semarang, diharapkan kegiatan pariwisata di Kota Semarang akan menjadi semakin semarak, apalagi bila Kota Lama dapat diusulkan sebagai kawasan World Heritage. Dengan berbagai keunikannya sebenarnya kawasan Kota Lama Semarang ini dapat dijadikan sebagai pusat kegiatan budaya dan pariwisata Semarang, sebab beberapa lembaga nasional dan internasional sudah mengakui akan keunikan Kota Lama Semarang, di antaranya mengusulkan Kota Lama Semarang sebagai Kota Pusaka dan sebagai World Heritage, yang dapat diartikan sebagai pusat pariwisata nasional dan internasional.

\section{Penutup}

Dari uraian terdahulu tentang Kota Semarang "tempo doeloe", dapat dikemukakan beberapa hal sebagai kesimpulan :

1. Semarang yang tumbuh pada jaman kerajaan Islam di Jawa dapat dikategorikan sebagai kota praindustri atau kota tradisional. Struktur kota ini memiliki keterkaitan kuat dengan latar belakang sejarahnya yang itu tercermin pada sisa-sisa peninggalan sejarah dan toponimnya.

2. Melalui pelacakan terhadap peninggalan sejarah dan perkampungan diketahui adanya keteraturan dan pola-pola yang sama pada struktur kota tradisional. Hal tersebut menunjukkan adanya perencanaan kota yang mengandung unsur historis-filosofis dan fungsional-praktis. Nama perkampungan seperti ini sekarang memang masih banyak ditemukan di Kota Semarang, namun umumnya masyarakat tidak mengenal sejarahnya lagi.

3. Pelapisan sosial yang cukup tajam, birokrasi pemerintahan yang sangat hirarki dan diferensiasi profesi telah mempengaruhi struktur keruangan kota dan pola pemukiman penduduknya, yakni berlakunya pengelompokan secara fungsional, etnik maupun mata pencahariannya. Dari sana lahir perkampungan-perkampungan (sub-urb) yang dari toponimnya menunjukkan ciri permukiman tradisional.

4. Karena segala keputusan politik dan ekonomi kurang didasarkan atas kebutuhan fungsi, profesionalisme ataupun kepentingan publik, tetapi lebih pada hubungan status, interpersonal dan kepentingan pribadi elit penguasa, akibatnya pertumbuhan kota cenderung lamban. Sampai dengan abad 18 pertumbuhan Semarang ditentukan oleh adanya tiga titik perkembangan, yaitu Kauman (pribumi/ tradisional), Kota Lama (Belanda/modern) dan Pecinan (Cina) dengan latar belakang budayanya masing-masing.

5. Dari latar belakang sejarahnya secara umum Kota Semarang berkembang berdasarkan keputusan politik. Memasuki abad 19, Kota Semarang tumbuh mengikuti konsep perencanaan modern 
(Barat) yaitu sebagai kota industri dengan ciri dan pola yang berbeda dari kota tradisional.

6. Aspek pelestarian cagar budaya dapat digunakan untuk memperkaya khasanah filosofis-historiskultural dalam perencanaan tata ruang Kota Semarang. Perkampungan selain menjadi salah satu identitas budaya kota, sekaligus juga simbol yang berfungsi memupuk kepercayaan diri, kebanggaan dan menumbuhkan etos kerja penghuni kota.

7. Seperti amanat Undang-Undang Nomor 11 tahun 2010 tentang Cagar Budaya, maka beberapa

\section{DAFTAR PUSTAKA}

Amen Budiman, 1978, Semarang Riwayatmu Dulu, Jilid Pertama, Semarang : Penerbit Tanjungsari. Brommer dkk., 1995, Semarang-Beeld van een Stad, Asia Major, Netherlands.

Buitenweg, Hein, 1975, Slenter Door Semarang, Amsterdam : Thomas \& Eras.

Burke, Gerald, 1971, Town in The Making, London : Edward Arnold.

Cortesao, Armando, 1944, The Suma Oriental of Tome Pires, vol. I, London : The Hakluyt Society.

Liem Thian Joe, 1933, Semarang (Dari Djamannja Sam Po Sampe Terhapusnya Kongkoan),

Tjitakan Pertama, Semarang : TP.

Linnekin, Jocelyn, \& Handler, Richard, 1984, "Tradition, Genuine or Spurious", dalam Journal of American Folklore vol. 97. No. 385, by The American Folklore Society 00218715/84/3850273 1852.30/1, hal 273290.

Pemda Dati II Kodya Semarang, 1979, Sejarah Kota Semarang, Semarang : TP.

Roesmanto, Totok, 1998, Masjid Besar Kauman Semarang : Arsitektur, Pengembangan dan Konservasinya, (makalah seminar).

Schrieke, B., 1959, Indonesian Sociological Studies

: Ruler and Realm in Early Java, vol. II, s'Gravenhage.

Serat Kandaning Ringgit Purwa, Naskah KBG Nr. 7. Sjoberg, Gideon, 1960, The Pre-industrial City : Past and Present, New York-London : The Free Press. perkampungan dapat ditetapkan sebagai kawasan konservasi, yaitu merupakan kawasan yang dikendalikan, sebab ada beberapa bangunan yang berkategori cagar budaya yang harus dilestarikan.

8. Kawasan konservasi dimaksudkan sebagai kawasan cagar budaya (tangible), disertai pula adanya pelestarian budaya yang bersifat intangible, seperti beberapa perkampungan dan kawasan di Semarang yang mengandung cagar budaya sekaligus juga sebagai tempat untuk melestarikan dan mengembangan budaya lokal yang ada.

Spradley, James P., 1972, Culture and Cognition : Rules, Maps, and Plans, San Fransisco, Scranton, London, Toronto : Chandler Publishing Company.

Soekirno, 1956, Semarang, Semarang : Djawatan Penerangan Kota Besar Semarang.

Tilly, Charles, 1978, An Urban World, Boston-Toronto : Little Brown \& Company.

Tim Telaga Bakti Nusantara, 1997, Sejarah Perkereta Apian Indonesia, Jilid I, Bandung : Penerbit Angkasa.

Tjandrasasmita, Uka, 1985, “Kota Pemukiman Masa Pertumbuhan Kerajaan-kerajaan Pengaruh Islam di Indonesia (Penerapan Arkeologi dan Konsep-konsep Ilmu Sosial)", dalam Proceeding Pertemuan Ilmiah Arkeologi III, Jakarta Puslit Arkenas.

Undang-undang Nomor 11 Thun 2010 Tentang Cagar Budaya

Valentijn, F., 1726, Beschriving van Groot Java op te Java Major, deel IV, Dordrecht : Joannes van Braam.

Wilmott, Donald Earl, 1980, The Chinese of Semarang A Changing Minority Community in Indonesia, New York : Cornel University Press.

100 Tahun HBS V Semarang 1877-1977, 1977, Panitia Reuni 100 Tahun HBS V Semarang. 